\title{
The first records of Scutigera coleoptrata (Linnaeus, 1758) (Chilopoda: Scutigeromorpha: Scutigeridae) from Belarus
}

\section{O первых находках Scutigera coleoptrata (Linnaeus, 1758) (Chilopoda: Scutigeromorpha: Scutigeridae) в Беларуси}

\author{
A.M. Ostrovsky \\ A.M. Островский \\ Gomel State Medical University, Lange str. 5, Gomel, 246000 Republic of Belarus. E-mail: Arti301989@mail.ru \\ Гомельский государственный медицинский университет, ул. Ланге 5, Гомель, 246000 Республика Беларусь.
}

KEY WORDS: Scutigera coleoptrata, faunistics, synathropy, Belarus.

КЛЮЧЕВЫЕ СЛОВА: Scutigera coleoptrata, фаунистика, синантропия, Беларусь.

ABSTRACT. The first records of Scutigera coleoptrata (Linnaeus, 1758) in Belarus are provided, one in the city of Brest and the other in the city of Gomel. Both records are clearly synathropic.

РЕЗЮМЕ. Приведены сведения о первых находках Scutigera coleoptrata (Linnaeus, 1758) в Беларуси, одна в городе Бресте, а вторая в городе Гомеле. Обе находки явно синантропные.

The centipede fauna of Belarus is still poorly-known. Altogether, only eight species have hitherto been recorded in the country, including five Lithobiomorpha and three Geophilomorpha [Maksimova, 2014]. The chilopods have solely been reported from natural habitats. As regards the anthropogenic habitats in Belarus, we can add here the house centipede, Scutigera coleoptrata (Linnaeus, 1758).

The order Scutigeromorpha, and the family Scutigeridae it belongs to, are both distributed almost worldwide, occurring on all continents except Antarctica, on all major islands and many oceanic archipelagos; numerous records refer to introduced populations of $S$. coleoptrata [Bonato, Zapparoli, 2011].

$S$. coleoptrata is a synanthropic species which is most common indoors in cities. Active expansions of the species into Ukraine and Russia have been observed over the last two decades [Merzlikin, 2013; Nefediev et al., 2016].

This species was first recorded in southeastern Belarus in the early 2000's in the cellar of a house in the city of Gomel. The house centipede has recently been found also in the city of Brest [O.I. Borodin, pers. comm., 2015] (Fig. 1).

$S$. coleoptrata becomes an increasingly ordinary, no longer rare, synanthropic species in Belarus. This species is listed in the Red Data Book of Ukraine [Tarashchuk, 2009], in the red data books of the Dnepropetrovsk [Brigadirenko, 2011] and Kharkiv regions
[Bartenev, 2013], as well as of the city of Kramatorsk, Donetsk Region, all in Ukraine [Vysochin, 2010].

\section{References}

Bartenev O.F. 2013. [The house centipede, Scutigera coleoptrata (Linnaeus, 1758)] // Shandikov G.A., Atemasova T.A. (eds.). Chervona kniga Kharkivskoy oblasti. Tvarinniy svit [Red Data Book of the Kharkiv Region of Ukraine. Animal world]. Kharkiv: V.N. Karazin Kharkiv National University. P.55 [in Ukrainian].

Bonato L., Zapparoli M. 2011. Chilopoda - Geographical distribution // Minelli A. (ed.). Treatise on Zoology - Anatomy, Taxonomy, Biology. The Myriapoda. Vol.1. Leiden-Boston: Brill. P.327-337.

Brigadirenko V.V. 2011. [The house centipede, Scutigera coleoptrata (Linnaeus, 1758)] // Pahomov O.E. (ed.). Chervona kniga Dnipropetrovskoy oblasti. Tvarinniy svit [The Red Book of

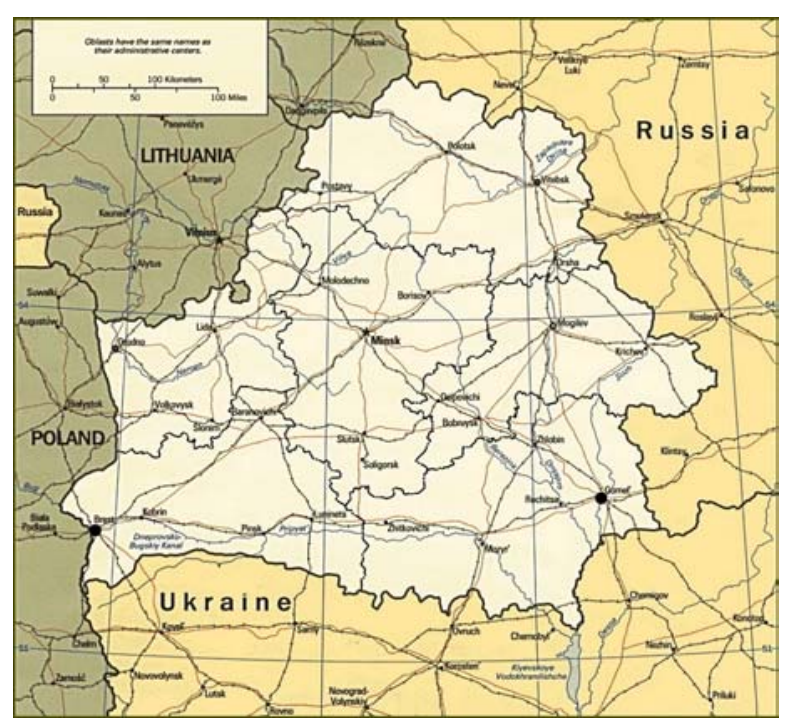

Fig. 1. Collecting localities of Scutigera coleoptrata (Linnaeus, 1758) in Belarus.

Рис. 1. Места находок Scutigera coleoptrata (Linnaeus, 1758) в Беларуси. 
the Dnepropetrovsk Region. Animal world]. Dnepropetrovsk: New Seal Publ. P.44 [in Ukrainian].

Maksimova S.L. 2014. [The species composition of centipedes (Myriapoda, Chilopoda) of Belarus] // Vestsi Natsiyanal'noi akademii navuk Belarusi. Ser. biyal. navuk [Proceedings of the National Academy of Sciences of Belarus. Biological Series]. No.4. P. 91-94 [in Russian].

Merzlikin I.R. 2013. House centipede Scutigera coleoptrata in Ukraine: a rare species becomes an ordinary synanthropic one // Invasion of alien species in the Holarctic. The IV International Symposium. Yaroslavl: Filigran Publ. P.117.

Nefediev P.S., Tuf I.H., Dyachkov Yu.V., Efimov D.A. 2016. The first record of Scutigera coleoptrata (Linnaeus, 1758) in the
South of Western Siberia, Russia (Chilopoda: Scutigeromorpha: Scutigeridae) // Biological Bulletin of the Bogdan Chmelnitskiy Melitopol State Pedagogical University. No.1. P.428-432.

Tarashchuk M.V. 2009. [The house centipede Scutigera coleoptrata (Linnaeus, 1758)] // Akimov I.A. (ed.). Chervona kniga Ukrainy. Tvarinniy svit [The Red Data Book of Ukraine. Animal world]. Kyiv: Globalconsulting Publ. P.59 [in Ukrainian]. Vysochin M.O. 2010. [The house centipede Scutigera coleoptrata] // Vysochin M.O., Tupikov A.I. (eds.). Po stranitsam Krasnoi Knigi g. Kramatorska [To the Red Data Book of Kramatorsk (Animal world). Guide]. Kramatorsk. P.10-11 [in Russian].

Responsible editor S.I. Golovatch 